\title{
都市ごみの機械的分別に関する研究 (2)
}

\author{
一湿式分別技術一
}

内 藤 幸 穂*

\section{2. 湿式分別技術}

\section{(Liquid Media Saparation)}

\section{1 概 説}

重力または遠心力の場における粒子の沈降速度を利用 して粉粓体を粒度によって分ける分別操作は，液体（普 通には水）中で行われる湿式分別と，気体（普通には空 気）中で行われる乾式分別と，最近通産省工業技術院の 指導のもとで開発しようととしている半湿式分別とに大 分類されよう。

常温における水の粘性係数は空気の約 50 倍であり, 同 じ固体粒子であ水中と空気中とではその沈降速度が異な り，水中の方が速度が小さいのが普通である。また空気 中では粒子の凝集する傾向が水よりあ一般に強く, 分散 剂の使用あ困難であるために，乾式分別では粗粒の産物 中への微粉の迷い込みがとくに抢てり勝ちである。

湿式分別機としては，重力沈降方式の歴史が古いが， 最近, 遠心沈降方式のものが急速な進出を示しており, 分別効率む一段之向上してきた. 近年分別技術が廃棄物 処理の分野で使用されるようになってから，湿式分別と 破础とを同時に行うととのできる湿式破哗分別機が発達 した.

\section{2 湿式分別機の種類1,2)}

（1）静的分別機 面積律をそのまま応用して，静的重 力沈降之越流による分別を行う型式の分別機で，むっと あ原姶的なあのである．粗粓分別用のコーン型のあの， 多産物分別を行うトイ型のあの，乙の両者の組合せ型と いえるスピカステン型などがある、コーン型の代表的な あのはアレン・コーン型で，スピゴットの自動排出機構 を備えている. これらの分別機は分别精度が低く，しか あ供給量の変動によって分別点が変わりやすいので, 近 代工場ではあまり顧りみられない。トイ型は陶土工業に 扔いて, 固体含有率 $10 \%$ 以下という比較的低濃度のパル

*内藤幸穂事務所 - 所長 工博

武蔵工業大学講師
プを分別する場合などに用いられている。

（2）水力分別機 向流分別機ともよばれるこの種の分 別機は，垂直または斜め上向きの水流（整流または脈動 流）の干渉によって，細かい粒子を沈降させるという分 離機構を有する．乙の種の分別機は供給量の変動による 分別成績の变化が少ないという点に特長があり，また比 較的粗い分別屯可能である. しかし細かい方の産物（才 一バーフロー）に高い濃度が要求される場合には適さな い. 単室式の代表的なあのとしては，フンボルト型向流 分別機があり, 多室式のものにはファーレンワルド・サ イザーがある.フンボルト型ではタンク上部のスリット のところで分別が行われる，スリットの幅を段階的に变 えることによって多産物分離用に設計することができ る.

ファーレンワルド・サイザーは, ティータ・コラムに おいて干渉沈降による分別が行われ，コラム内のパルプ 濃度を検出して粗粒産物は自動排出する機構となってい る.ドルコ・サイザーは，乙の自動排出機構を改良した あので, ドルコ・ジェットサイザー式はコラム底部の水 が吹き出す網をディストリビューション・パイプに変更 した型式である。

ひょうたん型の外形をあつエデル・カミング式垂直流 分別機は，上つぼまりの分别コラムを利用したあので， 分別点に近い粓度の粒子がコラム内に留まって分別性能 を阻害することをさけた点に工夫が施してある.

（3）機械分別機 粗粒産物を機械力によってまき出す 構造の分別機を機械分別機といい，かき上げ機械によっ てレーク方式とスパイラル方式とに大別される・レーク 方式の代表的なあのは，いわゆるドル・レーク分別機で ある.

スパイラル方式の代表はエーキンス・スパイラル分別 機であろう.レーク分別機と比較して搔き上げ産物の水 分は高目であるが，機構が簡単で故障が少ないとと，休 転・姶動が容易なとと, 占有床面積がやや小さいととが 特長である. スパイラル方式としてはてのほかに，ドラ ム型タンクの内面にスパイラル・リボンの付いたハーデ 
ィンジ向流分別機がある．ドラグ分別機，レーク方式の あっとあ簡単なあのである. 分別精度はよくないが，大 雑把でよい仕事に対してはしばしば使われている。微粒 分別用の標準機として㕕く用いられているボウル分別機 は，レーク分別機に小さな円形沈降タンクを付加したよ うな構造である。乙れを簡易化した新型分別機としてボ ウル・デシタルがあり, 土木関係などに使用されつつあ る.

レーク分別機に向流分別機を組み合せたドル・ハイド ロッシレーターは普通の向流分別機に比較して使用水量 が少なくてすみ，分別精度が他の機械的なそれよりあす ぐれているが, 機構の複雑なととが欠点である.

（4）遠心分别機 重力の代りに，遠心力を利用すると とによって 分别の 分離力を強めたのが 遠心分別機であ る.これには，サイクロン型と遠心分離型とがあり，こ れらは構造上ボウル型とカゴ型とに大别するととができ る. 作動原理の上からみると, 前者は遠心傾斜分離機の 方である。

遠心傾斜分離機を水平型と垂直型の 2 つ分けると， 前者はバード遠心分別機によって代表される.シャープ レス・スーパデカンタは, 構造はバードとほとんど同じ であるが，遠心効果がはるかに大きくなっている，スー パーデカンタにはバードと同じ円錐型と円筒型があり， 分別用として適しているのは前者で，乙の遠心効果は約 $2,100 \mathrm{G}$ で，約 $3 \sim 0.8 \mu$ までの分別が可能であるとい う.

垂直型の新しいものとしてはマーコ加圧遠心分離機を あげることができる．乙れは分離板式遠心分離機を改良 したあので遠心効果が從来のものにくらべて非常に大き くなっている（最大 $3,000 〜 9,000 \mathrm{G）ので，1 \mu までの}$ 分別が可能である.

（5）湿式破砤分別機 湿式破哗分別機は，直立円筒状 の水槽内にハンマー付特殊回転翼を有する破砤機で, 水 槽内には常に所定量の水が満されている. この機械は抄 紙回収用に開発された離解機（ハイドラパルパーともい われ，破哗力をあたない）に，ハンマーとステータを取 りつけて破砤力をあたせたあのである.

投入された混合芥のうち, 水に溶けやすい紙類, 屍芥 類は容易に解きほぐされ，どろどろのスリラー状態にな り，ちょうど電機洗たく機の内部を思わせるような状態 で回流している. ガラス, 陶磁器, 土石, プラスチック 等は高速で回転するハンマーの衡撃力で破破され，でみ スラリーと共に回転翼の下に設けられた多孔板を通過し て，ポンプで抜き出される，金属くず，空缶等とわずか の皮革類は多孔板を通過するほど小さくは破磔されない で，多孔板上方の 側面伍設けられた排出口から排出さ
れ，金属除去装置のバケットコンベヤで連続的に搔き上 げられた後, 磁選機に送られる. 特殊回転翼はギヤ一減 速機を介して, 電動機により駆動される.

本機は水中で破䂗を行うため, 破哗にともなう騒音お よび粉塵の飛散が少なく，かつ破哗機内部で粗選別が行 われる特長を持ち，液体サイクロンと組合せるととによ り，更に細い選利を行うプロセスをつくるととができ る.

\section{3 湿式分別機の問題点}

都市の生活環境施設としてのごみ処理施設を通観する に，炬による焼却がなお今後の主流となるであろうとと は否定できない，特に一時ブームを呼ぼうとさえした熱 分解 (Pylorisis) が，焼却炬との比較における高価格， 補助燃料の連続的使用等が原因して後退したことなどか

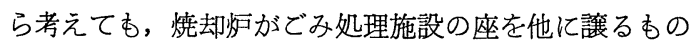
とは当分の間考えられない。

てのような立場にある焼却炬あ，プラスチックや重金 属などの混入した廃棄物を処理することにより，廃ガス や廃水による 2 次公害の原因者として指摘されるばかり でなく，自らの適応能力を越えて運転を強いられる結 果, その耐用年数は急速に減少する傾向にある。乙の上 うな背景をふまえて，各都市では既に家庭における分別 収集を採択し，資源化や再利用への方向をむ指向しつつ ある. しかし，家庭系からのでみの分別が成功したとし ても, 事業系のでみが多く混入する地域においては, 焼 却処理に不適当な成分を完全に分别することは困難とい わざるを得ぬ。このととから，収集搬入されたごみを焼 却処理場において分別し，混入したプラスチック類を取 り除くことによって焼却师の耐用年数をのばし，2次公 害を少なくする必要が生じるのである。

さて，でみからプラスチック類を回収する技術は，米 国包装工業界で開発され， $300 \mathrm{~kg} /$ 時の小規模ながら， ポリエチレン・ポリスチレン・PVC・ポリプロピレンの 分離を産物の劣化なく溶解法で行うととが可能となっ た 浮上・沈降分離によってポリプロピレン・ポリエチレン ・ポリスチレン・PVC の分離が米国鉱山局で完成した という報告あある 愁硬化性樹脂とが混合体のままあることに意義を認めな い工業会がニードに応じて開発した技術であるのだが， 焼却炬の耐用年数を延ばすためにでみの中からプラスチ ックを除去しようとする清掃事業者としての試みにおい ては,プラスチックが混合体のまま除去されてもさした る不都合はないのだが，再利用には不都合である。

一方ワーナー（Warner）は，処理場に向う大量のご みから含有率の少ないプラスチックを分離するととは容 
易なととではないと述へ，たとえ分離に成功したとして あプラスチックが激しく污されているととに問題が残る と述べている5 . 更に，付着した活れを洗浄するととが できたとしても，除去されたプラスチックの混合体から 一体誰が個々のプラスチックを分離しようとするのだろ うかと疑問を投げかけている。ワーナーの主張は，混合 プラスチックをそのまま利用できる道，たとえば，コン クリートのフィラーにする等の利用を考えぬ限り, 先行

いずれにしても，プラスチックの分離を可能性の高い あのにするには，地域ぐるみの協力を得て，紙・金属・ ガラスなどを分別収集し，でみ処理場の入口ではごみを 解础したのち破碎選別を実施するといった総合プランが 解决の鍵となるであろう．プラスチックの分別がたとえ 完成したとしても，でみ処理場に分別機を据付けてとと 足れりとするならば，それはあたかすコンポスティング 場にコンポストの格納場をつけ忘れたり，あるいはコン ポスト販売先の調査を怠って失敗した過去のコンポステ ィング事業の二の舞となる恐れがある.

\section{4 類似物質の湿式分別の実例}

（1）米国鉱山局に拉けるプラスチックの分別 米国鉱 山局が実験室規模で開発したプラスチックの分別におい ては，表 1 亿示す 5 つのプラスチック片につき，図-1の ような原理で浮上・沈降分離が行われた。乙の場合もし 溶媒を水にのみ限定すると，ポリオレフィン・ポリスチ レン・PVC に分けられるだけであったという。

普通の装置では, 先ず混合プラスチックは浮上・沈降

表 1 プラスチック片の種類

\begin{tabular}{l|l}
\hline 種 & 比 \\
\hline 類 & 重 \\
ポリエチ゚レン & 0.90 \\
ポリオレフィン & 0.92 \\
ポリスチレン & $0.94 \sim 0.96$ \\
P VC & $1.05 \sim 1.06$ \\
\hline
\end{tabular}
は暗いというあのである.

分離機に入り，浮上してポリオレフィンを除き，その他 のポリスチレンと PVC は路して水洗機（elutriation column）に入る. この水洗機では越流側にポリスチレ ンが集り，PVCは沈降側に入り，乙れを 2 次エアリフ トで取り出すのである． $25 \mathrm{~kg} /$ 時の実験装置による結果 は表 2 の通りである.

（2）コンクリート用骨材の穊分け6) コンクリート用 哗石の品質向上および規定粒度にするための節分機は生

表 2 浮上・沈降分離機に上る分別

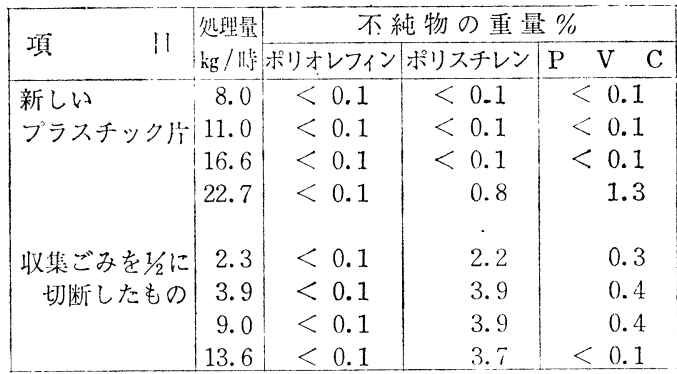

産工程上重要な役割を果すが，乾式をとるか湿式をとる かは設置場所の公害問題等によって决定される，湿式法 の長所は，原石に泥分が多く混入していている場合，粘 着目詰りなしに篩分けができる点にある，具体的には乾 式で用いられる振動節の代りに，ドラムウオッシャ一の トロンメルが使用される．又クラシャ一で破䂗された産 物に付着する泥分を除くため，篩上から水をかけて篩分 を良くする之ともに，水洗により産物の品質を向上させ ることができる，ただし， 2 次公害防止上水洗に使用さ れる水は，再循環して再利用することになるので，水処 理設備の投資が必要となる。

(3) 石灰の原石処理 ${ }^{7}$ 石灰工業においては，一定の 速度で均一な焼成を行うため，原石のサイズを一定に保 ち，かつ污れを取り除く工夫が計られなければならな い。そのため, 原石中の粘土質は水洗篩機によって处理 されるが，原石の表面に付着した粘土分の除去は難しい ので，強力な水洗篩分けが必要となる.

（4）製鉄業における飾分

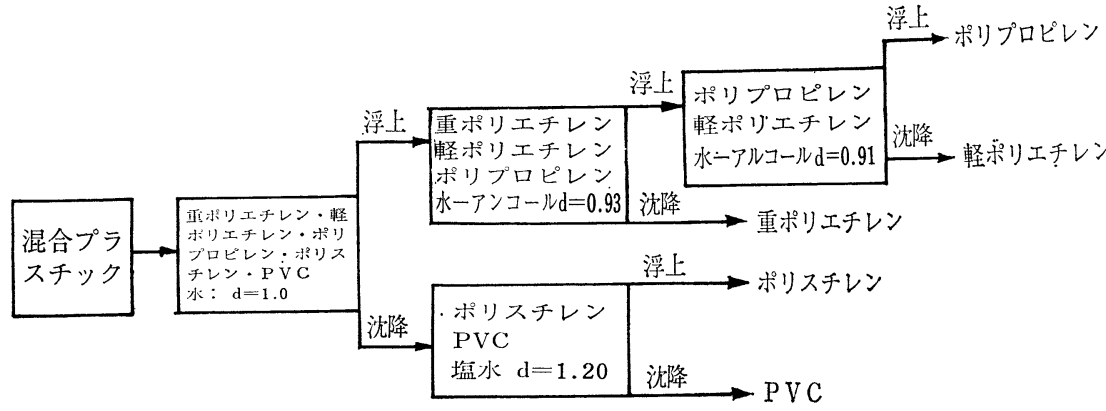

図-1 プラスチック片による混合プラスチックの分級
け8) 鉄鉣石の篩分けにお いては，付着水分が効率に かなりの影響を与えること が知られている. 付着水分 の影響をうける範囲は，精 鉱の下限 $(8 \sim 10 \mathrm{~mm})$ で あり，図一2に示すように， 水分が $6 \%$ 以上になると節 分け効率は急に低下する. これは同じ網を使用してい 
ても水分が多くなると龬に粉鉱が付着し，有効目開きが 小さくなるからである．また水分と迷込み率の関係は 図-3に示す如くで，水分 2 3\%の場合が迷込み率が最 小となり，水分が $3 \%$ より少ないと逆涪迷込み率が増加 している．乙れは網目に長穴を採用したため，水分の少 ない場合の節下産物中に精鉱の偏平鉱石が混入したため と思われ，角穴の使用が僸れているととがわかる.

(5) BHC 分別9) BHC (ベンゼンへキサクロライ ド）原料の分别は，要求される粒度よりみて粉础と分別 とを分離して考えることができない。これは BHC が単 なる粉体と異なり，低軟化物でありかつ凝集性および付 着性があるからで，分別以上に粉浒がむずかしく，分別 機の性能は高度のものが要求される.

これらの要求に応じて開発されたのが, ミクロン・ミ ルとミクロン・セパレーターの組合せで, 前者は粉哗機 内部の通過空気量を大きくし，冷却効果を高めるととも に粉碎室と粉础板の間隔を大きくし, 粘着と付着を防止 している. 後者はローターの回転による遠心力と, ロー ターの内向気流による向心力の差によって分別を行うも のである.

\section{5 湿式分離を備えたごみ処理法}

(1) 米国フランクリン・プラントの概要 米国のブラ ック・クローソン (Black-Clowson) 社が新しく開発し た資源回収型湿式でみ処理システムは, 故紙再生技術か ら発達したあのである. 従来故紙を再生する場合, 故紙 から紙以外の異物を完全に分離し取り除くことは不可欠 の技術と言われていたが，同社はこれをでみ処理に応用 し試験研究を進め, フランクリン市に 150t/日の試験プ ラントを建設し1971年 6 月より稼動を続けている. 本プ ラントは米国環境保護庁から 130 万ドル，フランクリン 市から50万ドルの補助金をうけ, 総額 200 万ドルを費し て建設したもので，次のようなシステム・フローを有す

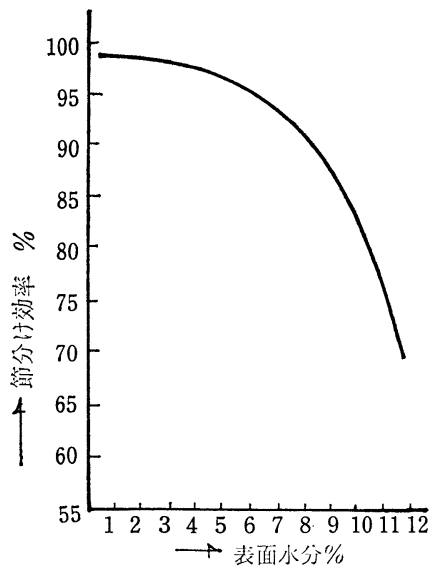

図-2＼cjkstart表面水分之穊分け勃率の関係

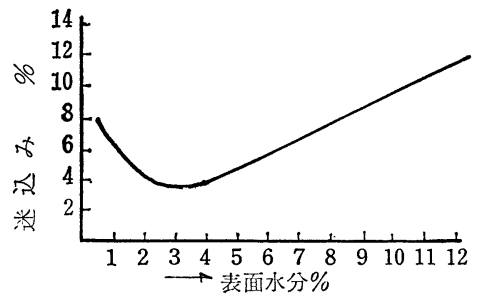

図-3 表面水分と迷込み\%の関係
$3^{10)}$.

イ、破硴とスラリー化

ごみは計量器で計量されたのちダンプフロアに投下さ れ, ショベルローダによりピットの中に落されると, コ ンベヤの働きで湿式破哗分別機（ハイドラパルパー）に 水と共に供給される，乙とで解きほぐされスラリ一状と なったでみは，底面にあるスクリーンを通ってポンプに よって抜き出される.

\section{口. 金属類回収}

ハイドラパルパー内でも破砤されない金属類は，底面 のスクリーンを通過せず，パルパー本体の側面に設けら れた開口部へ落ち、シュートでジャンクリムーバーとよ ばれる金属類排出装置に導かれ，搔上げられて洗浄され た後，磁選機によって金属類が鉄，非鉄金属に分離され る.

八.ガラスとアルミ回収

ハイドラパルパーからポンプで抜き出されたスラリー 状のごみは，液体サイクロンによって不然性ごみ（比重 の大きい金属片，ガラス片，砂利など）の大部分之固形 プラスチック片の一部が分離される，不燃性でみは空気 による比重選別を行って，比較的軽いアルミ・プラスチ ック類, 重い金属片, 中間の重さのガラス粒子に分離さ れる。

二. 製紙用パルプ再生

前述の工程で金属・ガラス・砂利などの不燃性重質でみ が分離された残りのスラリ一状のごみから製紙用パルプ を回収する方法は，製紙業界の故紙回収方法之同様であ るが, 本研究と直接関係がないのでととでは省略する.

木. 有機性残渣の処理

製紙用パルプ再生工程で除去された非回収性有機性残 渣は, 濃度 3〜 4\%のスラリー状態でいったん館蔵タン クに貯えられる. 有機性残渣は，先ず脱水機で固形分 40 〜45\%まで脱水し，流動燃焼炬にブロワーで風送され焼 却される。焼却炬頂部で $950^{\circ} \mathrm{C}$ 前後になった排ガスは， 灰之共にベンチュリスクラバー状に導かれ，除じん・脱 具・冷却処理されて大気中に放出される。ベンチュリス クラバー洗浄水は循還使用され，灰で濃度の高くなった スクラバー廃水はアッシュポンプで系外俳出される。

へ. 水処理

湿式破哗分別機へのプロセ ス用水，およびスクラバー用 水は，循還再使用されるが， 水処理設備としては隣接した フランクリン市下水処理場で 都市下水之まぜて処理されて いる. 
(2) 同プラントの運転結果 ${ }^{11)}$

1. 基本事項

ハイドラパルパーのあとに遠心分離機をつけ，スラリ 一中の不然物・ガラス・アルミを分離することが成功し た. 無機性土砂類が大変多いので, 当初つけていたサイ クロンを，鉱山でしばしば用いられる型のものにとりか えて分離に成功した。

ロ. パルプの回収

パルプの回収は純度の点で問題が多かったが，1つの 試みとして，スラリー状のごみに苛性ソーダを少し加え て $17.5^{\circ} \mathrm{C}$ で煮沸し, 洗浄し, スクリーンにかけ, 再度洗 浄してボール紙に向いた品質のものを得たし，また漂白 工程を加えて更に上質紙用に向上することに成功した.

\section{八. 鉄分の回収}

ジャンクリームーバと磁選機によって90～95\%の鉄分 が除かれるが，残りは多くのガラスと交ってしまいサイ クロンでは取り除けなかった. 錫分はハイドラパルパー の円围に集りその量は生ごみの $7 \%$ 亿んだが，アルミ との混合体のため $50 \mathrm{~kg} / \mathrm{m}^{3}$ といった低いカサ比重であ った.でみの中から回収される鉄分は，鉄分そのもので なく, 錫やアルミや有機質との混合体でしかない.そこ で薬品を加えてカン類の表面の錫を取り除く工夫も行わ れているが，決して容易なととではない。

(3) 同プラントの評価

イ.スケールアップの問題

スケールアップは製紙工場で採用しているあのを利用 すれば十分である．例えばフランクリン市のハイドラパ ルパの直径は約 $4 \mathrm{~m}$ で 200t/日のごみを処理したが， $800 \mathrm{t} /$ 日では直径を約 $7 \mathrm{~m}$ とし， $2,000 \mathrm{t} /$ 日のプラントで は約 $7 \mathrm{~m}$ のものを 3 台設備すればよい. 遠心脱水機など はフランクリン市の寸法のものを規格品とし, 大プラン トではその台数を増せばよい.

ロ. 図-4に，クローズドシステムの $150 \mathrm{t} /$ 日プラント のマスバランスを示すが，乙の場合は補助然料は考えて いない.

\section{6 わが国における実施例}

（1）まえがき 東京都下東久留米市の柳泉園組合に建 設された150t/日の湿式ごみ処理システムは，2.5で述べ た米国ブラック・クローソン社の開発による技術を石川 島播磨重工業侏で導入したもので，1961年技術提携した 製紙機械全般，1973年 2 月追加提携した湿式廃棄物処理 がその核をなしている。

米国ブラック・クローソン社の第 1 号機は, 2 ・5で述 べた如く，オハイオ州フランクリン市に設置され運転さ れているが，フランクリン市は田舎の都市である関係 上, 各種の公害規制がそれ程撖しくないので, 公害対策
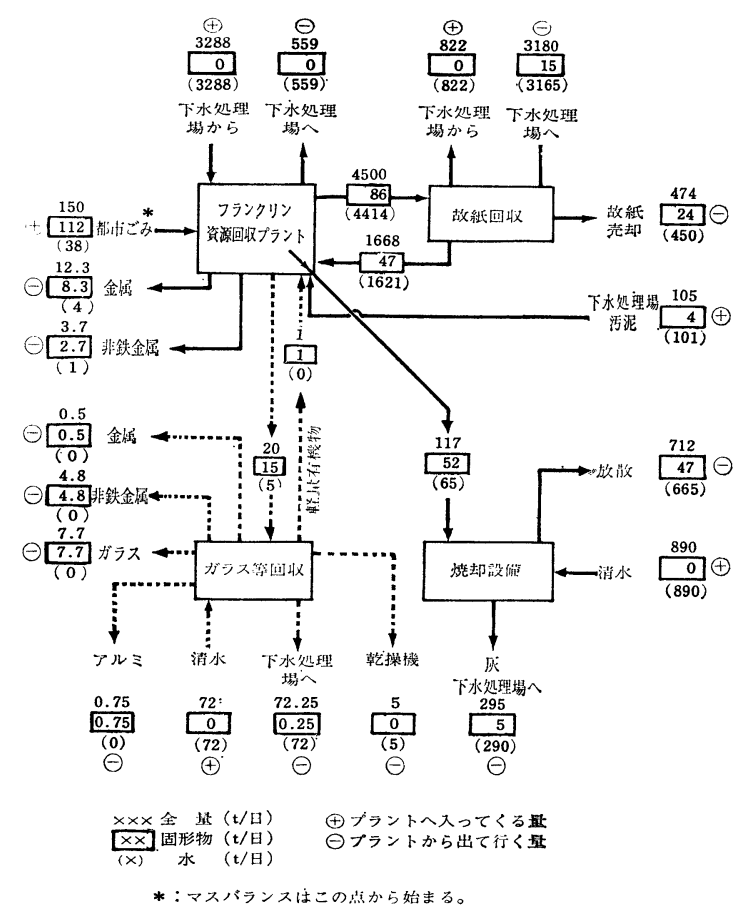

図-4 フランクリン資源回収型プラントのマ ス・バランス

は排水処理を除いてほとんど考慮されていない10).また 同社が現在ニューヨーク州ヘンプステッド市に建設中の $2,000 \mathrm{t} /$ 日プラントは， $50,000 \mathrm{KW}$ の発電を目的とする あのの, 紙パルプの回収は考慮されていない.

このような地域特性を勘案した設計方針は. 本技術が 日本で実施に移される場合には，当然厳しい規制の枠の 中で如何にあるべきかが問題となる，そのため，石川島 播磨重工業では先ず日本における湿式ごみ処理システム IHI-BC 方式を確立し，ついで日本における第 1 号機で ある柳泉園に扔いて実施化した，以下それらの内容につ いてのべるが, 先ず設備全般についてふれ，ついでサブ システムとしての湿式分別に言及するとととする.

(2) IHI-BC 方式

イ. 給塺・破哗

ごみ収集車によって集められたでみは，従来と同一型 式のピットに落され，クレーンによってピット室に設け られたエプロンコンベヤ上にのせられる．ピット室は全 閉式で僅かに負圧とされ，臭気は然焼空気としてボイラ に供給される．破哗機は米国式の同一型式で，水槽本体 はコンクリート巻きされ，防音型としている.

ロ. プラスチック分離装置

フランクリン方式における液体サイクロンは，ガラス や土砂等を効率よく分離するが，プラスチックの分離は 
必ずしあ十分でない。

米国におけるごみのプラスチック含有率は, 日本の約 5 分の 1 程度といわれ，プラスチックを多量に含んだで みを焼却することに対する 2 次公害は日本程深刻でな い.

都市ごみ中のプラスチックの形態を調べると, 大略重 量的に 3 分の 1 がフイルム状であり，その大部分はポリ エチレンとポリスチレンである。乙れらは燒却してあ有 害ガスの発生は少ないが，炬やその他の機器をいためる ことに変りがないので, 選别除去することが望ましい. 塩化ビニールは重量的には約 3 分の 1 程で, フイルム状 のあのは少なく，破砤機で破哗され扁平細片あるいは粒 状となる。

次に塩化ビニールの除去については, 第 1 次液体サイ クロンにつづいて，塩ビ除去を目的とした第 2 次液体サ イクロンを完成させた．この 2 次サイクロンは 1 次サイ クロンに比し, 形状・寸法・流速を全く異にし, 塩ビの 大部分を分離するのみなず，1次サイクロンで除去され なかった微細な粒子や砂の類もとてで除去するととが できる。

フイルム状プラスチックの除去は，その性質上液体中 では困難であるので，図-5に示す如く，有機性残渣とし て脱水された後，焼却炉投入直前の段階にて空気式選別 を行う.すなわち，水分55\%前後に脱水された残渣は， 容易にほぐれて均質の粒状然料となり, 直ちに空気式選 别機に入り，フイルムの殆んぞすべてが除去される．か くて焼却炬に連続定量投入され，安定然焼するてとにな るわけであるが，ここにおいて認識しなければならない ことは，むはや有用物は勿論，不然物打よび，燃却不適
物むととごとくといってよい程除去されてしまっている ということである.

分離されたフイルム類は, 若干の夾雑物ああるが, 純 度がよいので, 別ラインで溶融成形あるいは油化するて とあ可能となる.

\section{八. 循環水之水処理}

破䃏機に投入された水は，スラリーとなり，一連の機 器を通過し脱水機に至り, 分離され, 循環水貯蔵にいっ たん貯えられた後, 再び破砤機に供給される.

この循環水は, 原則としてクローズド・システムで処 理され再使用される. 循環水量はごみの一日の処理屯数 の約 3 倍重量相当であり, その水質は浮遊質約 $5,000 \mathrm{pp}$ $\mathrm{m}, \mathrm{BOD}$ 約 $30,000 \mathrm{ppm}$ 之推定される. 図一6は水処理装 置のフローシートであるが，そのベースは石川島播碞重 工が米国のスエンソン社と技術提携しているスエンソン 型エバポレータを改良したものである・後述のボイラに より発生せる弥気の一部をての装置に供給し, 污水を加 熱し蒸発を 2 段行い冷却して清水を得, 復水貯蔵された あと, シール水等プロセス用水として使用される. 同時 に発生する濃縮ケーキは, 有機性残渣の方に導き共に焼 却する. この清浄水の一部は余剩水として系外に放出す ることあできる.

二. 焼却炬・排ガス処理

焼却施設としてはバークボイラの改良型で，炬床はピ ンホールグレート固定式, 然料は燃焼空気の一部を以て 噴射式で炉内全般に連続配布される。灰出しはグレート に配置された蒸気ノズルによって適時行い，重金属含有

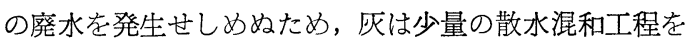
経て半練状として取出されるので, 運搬す容易となる.

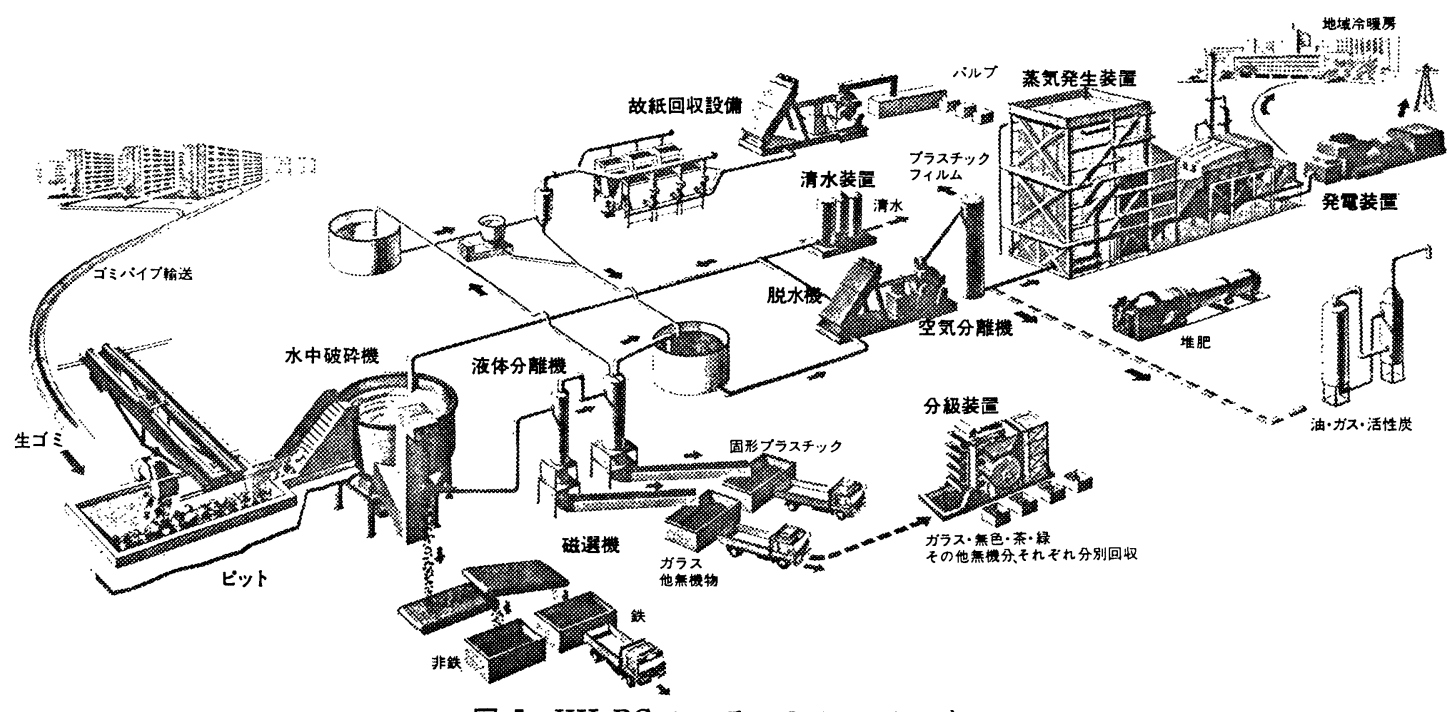

図-5 IHI-BC システムのフローシート 


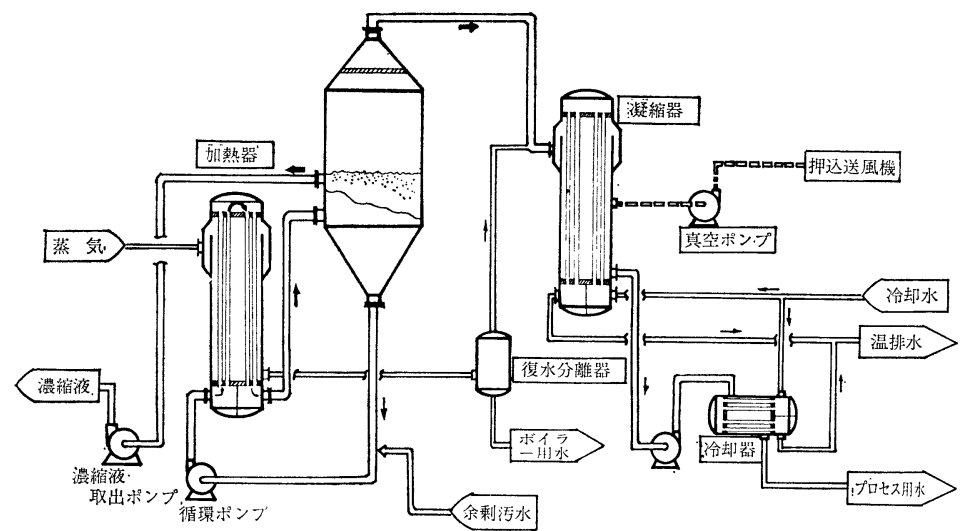

表 3 生ごみ組成

図-6 水処理装置フローシート

炉内温度はNOx 発生ならびにCl ガスに対処してコント ロールされる. 発生する熱は蒸気として回収される.ボ イラ通過後の排ガスは予熱器, 電気集塵器を経て煙突か ら大気放出される.この排ガスならびに廃水は, 焼却不 適物を除去してあるため, 従来の方式に比し, 重金属む 塩素化合物む極めて少なく，また灰の量むはるかに少な W.

ホ. 回収エネルギー

資源回収型プラントの特長として, ボイラーより発生 する蒸気は普通発電に向けられ, 他の一部は污水の浄化 に，また発電の一部はシステム内の 動力に消費される が, 残りは売電することになる. 従来他のプラントで発 電の殆んど自己消費に向けられ，売電の例が皆無に近か ったのは，一に安定発電の困難性に起因しているが，均 質な有機性残渣を利用した発電では蒸気発生に山谷がな く, 最大限に能力を発揮すること ができよう。

（3）柳泉園プラント 柳泉園組 合は東京都下東久留米市に位置 し, 東久留米市・田無市・清瀬市 ・保谷市の都市ごみおよびし尿を 一括処理している一部事務組合で ある.ごみ処理については，既設 の300t/日 焼却炬があるが，今回 IHI-BC 型プラント 150t/日を建 設した。

柳泉園プラントでうけ入れるご み質は，表 3 に示す如くで，乙れ は昭和 47 年度調査の 4 市平均ごみ 組成である。

てれらの生ごみに対して, 柳泉 園では建設予算などの関係から資
源回収には当面力点をおかず，無公害性を第一として設 計し, 資源回収は将来の課題とするととにしている.し たがって, ガラス選別設備は設けず, 紙パルプ回収設備 あ研究用小型のものを設置するにとどめている. また， 発電は行わず, 蒸気の一部を補機類の動力としてタービ ンに供給している.

よって本システムから有価物として 回収されるもの は，とりあえず鉄とプラスチックフイルムとエネルギー のみであり，紙パルプは実験的に小容量にとどまる．分 離物としては, 非鉄金属・土砂・ガラス・塩化ビニール 等比重の比較的大きいプラスチック等の混合物で, 焼却 設備に悪い影響を考えるものは殆んど除去されるものと 考えてよい. なお，柳泉園プラントのフローシートは， 図一าに示す通りである。

以上のべてきたプロセスによって回収される物質を， 生でみと対比して整理したものが図-8である. 左端は昭

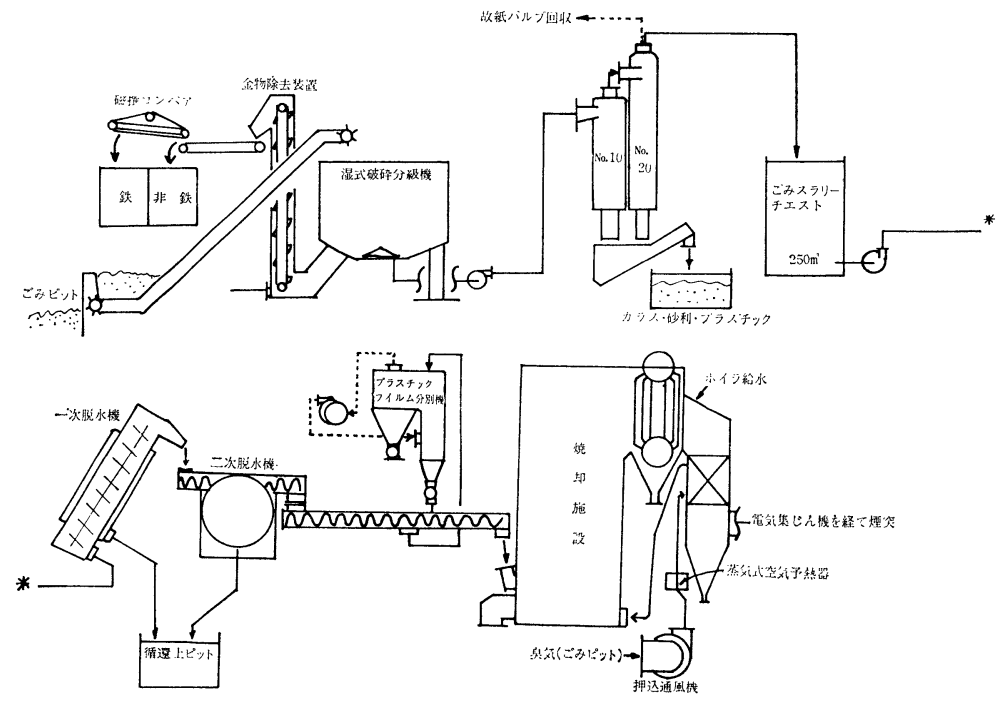

図-7 柳泉園プラントのフローシート 


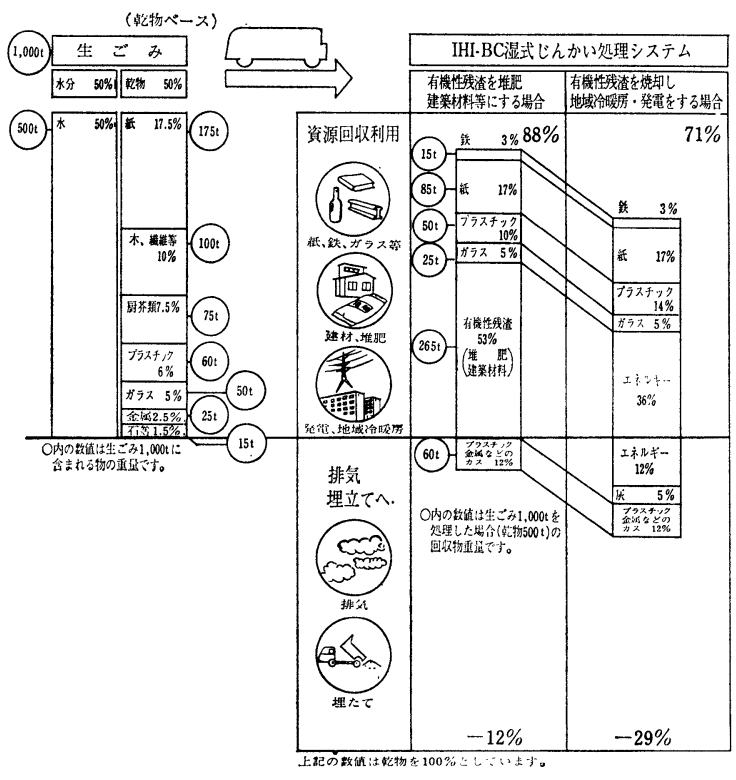

図-8 物質収支

和 47 年 5 大都市の平均の生でみ組成であり，すべて乾分 ベースで表現してある.

かくの如く，本プロセスは資源の回収が可能な他，年 間を通じて均質な有機性残渣が求められ，乙れは発電だ けでなく土地改良剤として，あるいは建築用ボード材料 さらには油化や活性炭製造にあ好適といえる. 特にごみ 収集に当り分別収集を行わずにすむととは，都市清掃事 業としてのメリットといえる.

\section{7 実機による分別システムの効果と評価}

IHI-BC 湿式分別システムにおいて, 諸機器の作動に よって分別される物質群は, 鉄・非鉄・ガラス・石陶器 ・プラスチック・有機性残渣の 6 種類と考えられる. し かしそれらの物質群の中には，互いに他の物質群がまじ り合い，完全にプュアな形で分別されるすのは望めな い. これは機械力による分别の当然の結果であり，人力 によらない限り $100 \%$ に近い純度の分别を期待すること は不可能と思われる.

（1）柳泉園プラントの生でみ組成

表 4 亿示す如く，生ごみの組成は かなりのバラツキが多く，僅かな資 料から平均值を求めたととは若干の 無理が感じられるが，他資料と比較 するとプラスチック類及び繊維類が 比較的多量に含まれている. しかし これは, 収集区域の特性からみて当 然の結果といえよう.

なお，乙れらの生ごみ組成が基準
表 4 生でみの組成

\begin{tabular}{|c|c|c|c|c|}
\hline 組 & No. 1 & No. 2 & No. 3 & 平均 \\
\hline 紙・セロハン類 & 50.9 & 57.12 & 42.17 & 50.06 \\
\hline 木 竹- 草 類 & 8.7 & 3.18 & 5.33 & 5.74 \\
\hline プラスチック類 & 5.0 & 8.21 & 5.93 & 6.38 \\
\hline 繊 維 類 & 2.5 & 5.24 & 3.56 & 3.77 \\
\hline ゴム・佊革類 & 1.0 & 3.79 & 1.94 & 2.24 \\
\hline 庇 芥 類 & 16.7 & 13.72 & 19.7 & 16.71 \\
\hline ガラス・石類 & 4.8 & 1.85 & 10.68 & 5.78 \\
\hline 金 属 類 & 5.6 & 1.89 & 2.0 & 3.16 \\
\hline 雑 物 $5 \mathrm{~mm}$ 以下 & 0.9 & 1.32 & 1.78 & 1.33 \\
\hline " $5 \mathrm{~mm}$ 以上 & 3.9 & 3.68 & 6.91 & 4.83 \\
\hline 合 & 100.0 & 100.0 & 100.0 & 100.0 \\
\hline
\end{tabular}

となって分別効率が論ぜられるわけだが，本プラントが 実機であるととろから，インプットとアウトプットとの 間にはタイムラグに基ずく性状のずれがあるため，分別 効率を評価する場合には，それらの特性を考慮しなけれ ばならない.

（2）各装置による分別結果 表 5 に示す如く，各装置 から分別された物質群の合計は $13.75 \%$ であるので，残 りの $86.25 \%$ は有機性残渣として排出されたととにな る.

1 次および 2 次液体サイクロンによっては, 比重が 1.2 以上のプラスチック類が分別されるので，比重1.2末 満のプラスチックは有機性残渣中に混合されるととにな る.なお，風選分别によれば，比重の大小に拘わらず， いわゆる軽いものは分别されることになる.

表一 5 に示した分別率をマクロ的に評価するなら，1 次液体サイクロンにおいて，ガラス $80 \%$; 鉄 $45 \%$; 非鉄 66\%; 石陶器99\%が分別されることになり，鉄分につい ては金属屑除去装置と 1 次液体サイクロンにおいてほぼ 99\%が分別されたとみるととができよう。

プラスチックについて述べるなら，比重の重い成形品 は，2次液体サイクロンで 分離する設計であったもの が，実際には 1 次液体 サイクロンで 分離される率が多 く，他はプラスチック風選設備で分別される傾向にある

表 5 実機による分別率

(生ごみを100とした乾燢隽\%)

\begin{tabular}{|c|c|c|c|c|c|c|c|c|}
\hline 装 置 名 称 & ガラス & 鉄 & 非鉄 & 石·陶器 & プラスチック & $\begin{array}{l}\text { 字の他の } \\
\text { 不姳物 }\end{array}$ & 有機性残椬 & it \\
\hline (1)金属風除去装置 & 0 & 0.9 & 0.1 & 0.1 & 0 & - & - & 1.1 \\
\hline (2) 1 次液体サイクロン & 1.7 & 0.7 & 0.4 & 2.6 & 0.2 & 3.5 & - & 9.1 \\
\hline (3) 2 次" & 0 & 0 & 0 & 0 & 0.05 & - & - & 0.05 \\
\hline (4)プラスチックフイルム風選設備 & - & - & - & - & 2.8 & - & 0.7 & 3.5 \\
\hline
\end{tabular}

注 (1) 表中 0 とあるは, その量が少ないため零とした.

(2) * は微粒子のため手分析ができなかったが, 非鉄・石・陶器がその大半を占 めているものと思われる。

(3) プラスチックフイルム風選設備は, ファンダンパ開度 $60 \%$ 場合. 
ととがわかった：その際の分別率は両液体サイクロンお よびプラスチック風選設備をあわせて約 $69 \%$ あ゙あ，今 後の改良に向上させる必要がある. 分別されたプラスチ ックのうち, 再利用可能な形として回収できるあのは, 主としてプラスチック風選設備から回収されるポリエチ レンおよびポリプロピレンフイルムである.

プラスチックの純度と風選用ファン出口ダンパ開度の 関係は，図-9に示す通りであり，開度をせばめれば当然 プラスチック純度は向上する.

以上を総括するに，実機の実運転による各物質ごとの 分別効率は表 6 に示す通りであるが，表中分別率が 100 \%をとえる矛盾は，生ごみ組成にバラツキがあるためで ある・

（3）分別物質群の組成分析および性状

イ・プラスチックの純度

実践によって分別されたプラスチックの純度を知り， ついでその回収の可能性を知るために，昭和 51 年 1 月 28 日より 2 日間にわたり採取した試料を手選別により仕分 けした結果を表 7 および表 8 に示す.

試料は 4 サンプルで， 夫々ビニール 袋に $1.5 \mathrm{~kg}$ 程度 つめたあのを約 $20 \mathrm{~km}$ 離れた実験室に運搬後手選別に付 したが，試料が大量でありかつ人員に制度があったた め, 試料に付着した水分の取扱いに困難を生じ，組成分 析值に水分の要素を加味することができなかった。した がって, 熱可塑性物質の純度としては, 真の值よりネガ テイブな值となっているととを付記しておくなお，4

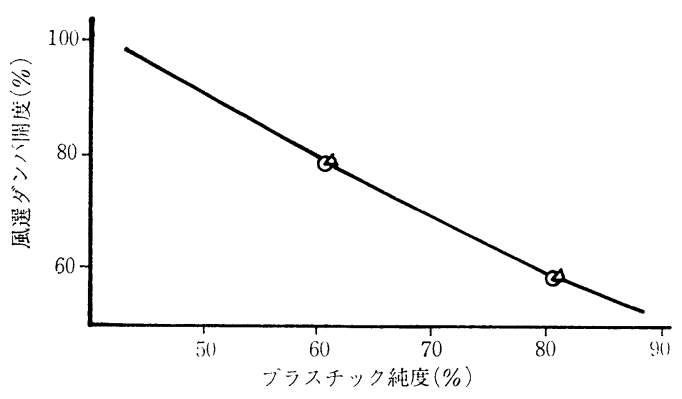

図-9 プラスチック風選設備により分離され るプラスチック純度

サンプルのうち， 2 サンプルはダンパ開後 $60 \%$, 他の 2 サンプルは開度80\%によるあのであったが, 図-9に示す 通り純度の評価において前者が当然後者を上廻る值を示

表 6 実機による分別効率

\begin{tabular}{|c|c|c|cr|c|c|c|}
\hline $\begin{array}{c}\text { 回收物留 } \\
\text { プラント全体 }\end{array}$ & ガ ス & 鉄 & 非 & 鉄 & 石 陶 器 & プラスチック & 備 \\
\hline 考 \\
\hline 分別効率
\end{tabular}

している・

ロ.ガラス

ガラスは水中離解機において破哗されるため，ガラス の角が丸味を帯び，排出および再利用の際の取扱いは比 較的容易である. また，水中破砤のためガラスに付着し ている污れがとれ，再利用の際の付加価值を増している

表 7 プラスチックの組成（\%)

\begin{tabular}{|c|c|c|c|c|}
\hline & \multicolumn{2}{|c|}{ 51. 1. 28} & \multicolumn{2}{|c|}{ 51. 1. 29} \\
\hline & $60 \%$ & $80 \%$ & $60 \%$ & $80 \%$ \\
\hline 無 機 物 & 0.2 & 0.4 & 0.9 & 0.5 \\
\hline 有機性残潹 & 19.7 & 41.3 & 18.8 & 46.1 \\
\hline 熱硬化性椞 & 0 & 0 & 0 & 0 \\
\hline 熱可塑性所 & 80.1 & 58.3 & 80.3 & 53.4 \\
\hline
\end{tabular}

表 8 熱可塑性質の組成（\%)

\begin{tabular}{|c|c|c|c|c|}
\hline & \multicolumn{2}{|c|}{51.1 .28} & \multicolumn{2}{|c|}{51.1 .29} \\
\hline & $60 \%$ & $80 \%$ & $60 \%$ & $80 \%$ \\
\hline $\begin{array}{ll}\mathrm{P} & \mathrm{P} \\
\mathrm{P} & \mathrm{E}\end{array}$ & 96.1 & 85.7 & 92.0 & 77.9 \\
\hline P V C & 2.3 & 8.1 & 15.0 & 27.0 \\
\hline $\mathrm{S}$ & 1.5 & 5.6 & 4.0 & 11.6 \\
\hline サラン系 & 0.1 & 0.6 & 0.6 & 1.0 \\
\hline
\end{tabular}

とあいえる・

柳泉園プラントには，ガラス選別装置が設置されてい ないが，フランクリンのプラントでは試験的にガラス選 別機が用意され， 6〜 19mm 经の粒度のものが無色・ 茶色・緑色の 3 種類に分別されてかなりの効果のあげて いる。

\section{八. 鉄金属}

鉄金属は主として水中離解機の金属屑除去装置加ら排 出させるが，水中離解機の働らきで鉄が一部除去され， 容積も比較的小さくなるので排出には便利である.

\section{二. 有機性残渣}

プラントより排出される有機性残渣は組成が均一で後 処理, 例えば焼却, コンポスト化にとっては好都合なも のである.

先ず, 発熱量については表 9 に示す如く, 1,100〜 $1,500 \mathrm{Kcal} / \mathrm{kg}$ と比較的安定した低位発热量を示してい る.

次に，有機性残渣中の重金属類を分析した 結果を表10に示した。乙の調査は，有機性残 渣が将来コンポスト化に移行するような場 合，土壌污染に関してどのように位置づけら 
表 9 有機性残渣発熱量分析結果

\begin{tabular}{|c|c|c|c|c|c|}
\hline \multirow{2}{*}{ 項 } & \multirow{2}{*}{ 目 } & \multirow{2}{*}{ 単位 } & 50.11 .13 & 50. 11. 18 & 50. 11.18 \\
\hline & & & $A B$ ライン混合 $(\mathrm{pm} 3.00)$ & Aライン $(\mathrm{pm} 3.00)$ & Bライン $(\mathrm{pm} 3.00)$ \\
\hline 水 & 分 & $\%$ & 64.61 & 61.73 & 57.56 \\
\hline 灰 & 分 & $\%$ & $7.03(2.19)$ & $8.53(3.26)$ & $8.88(3.77)$ \\
\hline 高位発 & 熱量 & $\mathrm{Kcal} / \mathrm{kg}$ & 4,470 & 4,297 & 4,478 \\
\hline 低位 & $"$ & & 1,091 & 1,163 & 1,441 \\
\hline 炎 & 素 & $\%$ & $43.34(15.34)$ & $42.57(16.29)$ & 38.82 (16.48) \\
\hline 水 & 素 & $\%$ & $5.64(2.00)$ & $5.60(2.14)$ & $5.17(2.19)$ \\
\hline 硫 & 黄 & $\%$ & $0.17(0.06)$ & $0.15(0.06)$ & $0.13(0.06)$ \\
\hline 篗 & 素 & $\%$ & $0.97(0.34)$ & $1.07(0.41)$ & $1.15(0.49)$ \\
\hline 䐪 & 素 & $\%$ & $0.28(0.10)$ & $0.13(0.05)$ & $0.12(0.05)$ \\
\hline 酸 & 素 & $\%$ & $42.57(15.06)$ & $41.95(16.06)$ & $45.73(19.40)$ \\
\hline
\end{tabular}

注 (1) 上記数值は各々 3 回分析した結果の平均.

(2) 脱水機以降 A，Bラインあり，灰出しの析は一方を中止.

\section{れるかを知るためのあのでるあ.}

（4）排出物及び回収物 分別システムを伴った燃焼装 置がどのように評価されるかというととは，分別システ ムそのあのにつながる重要な問題である.ただ単に所定 の生でみを焼却処理するというだけでなく，燃焼装置か ら排出されるばいじん量, 焼却灰の組成, 排水の特性な ぞを十分にチェックすることによって, 燃焼装置の価值 を高めることが必要である.

\section{イ. 蒸気}

柳泉園プラントにおいて，有機性残渣はバークバイラ によって焼却され，エネルギーとしての蒸気を回収して いる. 蒸気は補機駆動用タービン 4 台, 空気予熱器, 循 環水処理設備に利用され, 少量ではあるが焼却炬の灰出 し, ボイラチューブのすす吹器, 管理本館の暖房および 給湯用に利用されている。

実測によれば，蒸気量は $12 〜 16 \mathrm{t} / \mathrm{hr}$ で一般の生ごみ 焼却炬と比較して変化巾が小さく, 平均的に約 $14 \mathrm{t} / \mathrm{hr}$

表10 存機性残渣中の重金属類分析結果（日 本検査による)

\begin{tabular}{|c|c|c|}
\hline \multirow{2}{*}{ 項 } & \multicolumn{2}{|c|}{ 重 金 属 類 $(\mathrm{p} \mathrm{pm})$} \\
\hline & 51. 1. 28 & 51. 1.29 \\
\hline $\mathrm{T}-\mathrm{Hg}$ & $<0.0005$ & $<0.0005$ \\
\hline $\mathrm{Pb}$ & 0.21 & 0.07 \\
\hline As & $\therefore 0.005$ & $<0.005$ \\
\hline $\mathrm{Cn}$ & $\ulcorner 0.02$ & $<0.02$ \\
\hline$C d_{+6}$ & 0.01 & $<0.01$ \\
\hline $\mathrm{Cr}$ & $<0.05$ & $<0.05$ \\
\hline 有機リン & $<0.001$ & $\therefore 0.001$ \\
\hline $\mathrm{PCB}$ & $<0.0001$ & $\approx 0.0001$ \\
\hline $\mathrm{Ni}$ & 0.18 & 0.08 \\
\hline $\mathrm{Cu}$ & 0.12 & 0.37 \\
\hline $\mathrm{Zn}$ & 2.38 & 5.40 \\
\hline $\mathrm{T}-\mathrm{Cr}$ & 0.09 & 0.12 \\
\hline $\mathrm{R}-\mathrm{Hg}$ & $<0.0005$ & $<0.0005$ \\
\hline
\end{tabular}

の蒸気を得ている.

\section{ロ.ばいじん濃度}

焼却装置のインプットである有機性残渣が均一 性に富んでいるため，燃焼条件は一定之考えら れ，効率のよい集じん機の働らきで，集じん機出 口のばいじん量は表11に示す如く，規定值を大き く下回る結果を示している.

\section{八. 焼却灰}

有機性残渣の均一性は，焼却灰の分析結果によ い值をもたらしている．表12は石川島播磨重工の 手により，表13は日本検査㑣による分析結果であ る.

\section{二. 有害ガス}

実測によれば, $\mathrm{SO}_{2}$ は $60 \mathrm{ppm}$ 前後, $\mathrm{NOx}$ は $50 \mathrm{ppm}$ 前後, $\mathrm{HCl}$ は $120 \mathrm{ppm}$ 前後の值を得てお り，従来の焼却炬とくらべて稀色ない，

表11 ばいじん濃度測定結果

\begin{tabular}{|c|c|c|c|c|}
\hline & 則 定 条 件 & $\begin{array}{l}\text { 比じん滥度 } \\
\text { (乾き) }\end{array}$ & 平均值 & 測定位篔 \\
\hline \multirow{4}{*}{ I } & \multicolumn{2}{|c|}{ プラスチックフイルム问収なし $\quad \begin{array}{l}0.0192 \\
0.0151\end{array}$} & 0.017 & \multirow{4}{*}{ 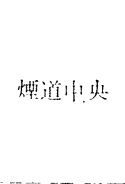 } \\
\hline & 灰沙乙山 & 0.0554 & 0.055 & \\
\hline & \multirow{2}{*}{ プラスチックフイルム回収有 } & 0.0258 & \multirow{2}{*}{ ().024 } & \\
\hline & & 0.0244 & & \\
\hline \multirow{5}{*}{ II } & \multirow{2}{*}{ プラスチックフイルム问收なし } & 0.006 & \multirow{2}{*}{0.006} & \multirow{5}{*}{$\begin{array}{l}\text { 煙道を9 分割 } \\
\text { トラバー天 }\end{array}$} \\
\hline & & 0.005 & & \\
\hline & 惊洁 L 中 & 0.022 & 0.002 & \\
\hline & \multirow{2}{*}{ プラスチックフイイルム叮収有 } & 0.005 & \multirow{2}{*}{0.005} & \\
\hline & & 0.004 & & \\
\hline
\end{tabular}

表12 焼却灰分析結果

\begin{tabular}{|c|c|c|c|c|}
\hline & \multicolumn{2}{|c|}{ 50. 11. 13} & \multicolumn{2}{|c|}{ 50. 11. 18} \\
\hline & A. $M$ & $\mathrm{P} \cdot \mathrm{M}$ & A. M & $\mathrm{P} \cdot \mathrm{M}$ \\
\hline $\mathrm{SiO}_{2}$ & 40.0 & 27.5 & 37.9 & 34.7 \\
\hline $\mathrm{Ai}_{2} \mathrm{O}_{3}$ & 20.1 & 17.2 & 19.1 & 17.7 \\
\hline $\mathrm{Fe}_{2} \mathrm{O}_{3}$ & 5.13 & 4.42 & 5.33 & 4.76 \\
\hline $\mathrm{MnO}$ & 0.25 & 0.27 & 0.25 & 0.25 \\
\hline $\mathrm{Mg} \mathrm{O}$ & 2.67 & 3.66 & 4.24 & 4.71 \\
\hline $\mathrm{CaO}$ & 17.5 & 17.7 & 19.6 & 13.6 \\
\hline $\mathrm{Na}_{2} \mathrm{O}$ & 6.56 & 11.7 & 7.88 & 9.43 \\
\hline $\mathrm{K}_{2} \mathrm{O}$ & 2.84 & 3.91 & 3.18 & 3.56 \\
\hline $\mathrm{C} e^{-}$ & i. 03 & 4.93 & 1.51 & 2.91 \\
\hline $\mathrm{SO}_{3}$ & 0.42 & 1.61 & 0.52 & $1: 17$ \\
\hline $\mathrm{TiO}_{2}$ & 0.52 & 1.07 & 1.65 & 1. .42 \\
\hline $\mathrm{Cu}$ & 0.14 & 0.15 & 0.20 & 0.17 \\
\hline $\mathrm{V}$ & $<0.01$ & $<0.01$ & $<0.01$ & $<0.01$ \\
\hline $\mathrm{P}$ & 1.66 & 1.47 & 1.70 & 1.75 \\
\hline $\mathrm{F}$ & 0.02 & 0.04 & 0.03 & 0.02 \\
\hline As & 0.001 & 0.001 & 0.001 & 0.001 \\
\hline $\mathrm{T}-\mathrm{Cr}$ & 0.07 & 0.06 & 0.06 & 0.05 \\
\hline $\mathrm{T}-\mathrm{C}_{2}$ & 0.93 & 1.82 & 0.80 & 0.90 \\
\hline $\mathrm{CO}_{3}$ & 1.69 & 5.03 & 2.39 & 3.74 \\
\hline 焼ビン減唇 & 1.97 & 2.44 & 1.73 & 1.54 \\
\hline PII & 11.1 & 11.5 & 11.1 & 11.2 \\
\hline
\end{tabular}


表13 焼却灭溶出試験結果

i侻侻品m

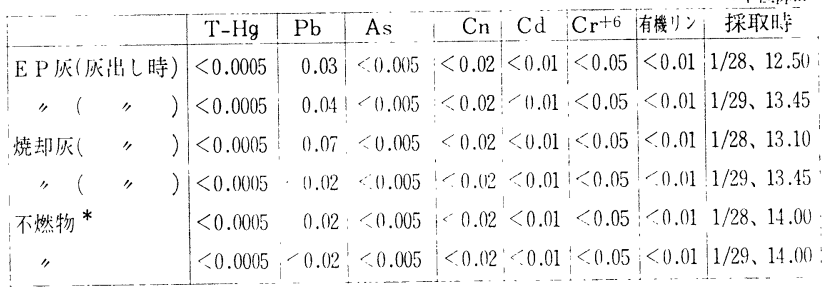

* : 重属屠除去装置, 1 次及 2 次サイクロンより鉄を除いたすの

ホ. 排水

本システムはクローズドシステムであるので, 活水循 環系からは排水が出ない. しかしクローズドシステムで あるが故に生ずる問題点は皆無とはいえないので，今後 更に改良する必要がある.なお，循環水処理システムよ り排出されるスラッジは, 焼却炬によって焼却処理され るが，その発熱量等分析結果は表14に示す通りである.

\section{ヘ. 悪臭}

湿式分別システムの中心となる水中離解機付近の臭気 を指摘されることがあるため，特に悪臭を発生すると思 わ机る物質について調へ，その結果を表15に示した。

ごみに起因する臭気構成物質を明らかにした調查事例

表14 スラッジ発熱量分析結果

\begin{tabular}{|c|c|c|c|}
\hline 項 & & 日 & 50.9 .19 \\
\hline 水 & 分 & $\%$ & 63.1 \\
\hline 灰 & 分 & $\%$ & $12.6(4.65)$ \\
\hline 高位発 & 熟俥 & $\mathrm{Kca} / \mathrm{kg}$ & 2,640 \\
\hline 低位。 & " & $\mathrm{Kcal} / \mathrm{kg}$ & 484 \\
\hline 炭 & 素 & $\%$ & $29.32(10.82)$ \\
\hline 水 & 素 & $\%$ & $5.31(1.96)$ \\
\hline 硫 & 黄 & $\%$ & $0.38(0.14)$ \\
\hline 室 & 素 & $\%$ & $1.93(0.71)$ \\
\hline 塭 & 素 & $\%$ & $0.13(0.05)$ \\
\hline 酸 & 素 & $\%$ & $50.33(18.57)$ \\
\hline
\end{tabular}

注 (1) 上記数値は各々 3 回分析した結果の平均值である.

(2) 分析は水分を除き乾燥試料として行なった.

(3)（）内は湿式ベースの值を示す.

表15環境臭気測定（日本検査による）

\begin{tabular}{|c|c|c|c|c|}
\hline 採取場 所 & $\begin{array}{l}\text { 室温 } \\
\text { 湿度 }\end{array}$ & トリメチルアミン & モノメチルアミン & メチルメルカプタン \\
\hline $\begin{array}{l}\text { 水中解離 機 } \\
\text { ブラットホーム前 }\end{array}$ & $\begin{array}{l}16.5 \\
50\end{array}$ & $\left|\begin{array}{cc|}(1) 0.017 & \bar{X} \\
\text { (2) } 0.013 & 0.015\end{array}\right|$ & $\begin{array}{lc}0.28 & \bar{x} \\
0.31 & 0.29\end{array}$ & 0.0014 \\
\hline $\begin{array}{l}\text { Bライン } 2 \text { 次脱水的 } \\
\text { 斜め通路中央 }\end{array}$ & $\begin{array}{l}16.5 \\
50\end{array}$ & $\begin{array}{l}(1) 0.008 \bar{x}^{\bar{x}} \\
(2) 0.009\end{array}$ & $\begin{array}{ll}0.24 & \bar{x} \\
0.16 & 0.20\end{array}$ & 0.0016 \\
\hline $\begin{array}{l}\text { 焼却㶰コンベア中間 } \\
\text { 通 路 出口前 }\end{array}$ & $\begin{array}{l}16.5 \\
45\end{array}$ & $\begin{array}{ll}1: 0.005 & \bar{x} \\
(2) 0.009 & 0.007 \\
\text { (3) } 0.08 & \end{array}$ & $\begin{array}{lc}0.14 & \bar{x} \\
0.10 & 0.11 \\
0.09 & \end{array}$ & 0.0013 \\
\hline
\end{tabular}

表16 ごみピット内悪臭成分例

\begin{tabular}{|c|c|}
\hline 筫 & ガス中濃度 $(\mathrm{ppm})$ \\
\hline トリメチルアミン & 25.67 \\
\hline メチルアミン & 5.37 \\
\hline n-プロピルメルカプタン & 0.65 \\
\hline ジエチルサルファイド & 1.39 \\
\hline メチルメルカプタン & 1.11 \\
\hline ジーnーブロピルアミン & 0.11 \\
\hline n-ブチルメルカプタン & 0.22 \\
\hline LSDアミルメルカプタン & 0.16 \\
\hline
\end{tabular}

は少ないが，京都大学がごみピット内で測定した悪臭を 測定した事例を表16亿示す。したがって，表15と表16 を比較する限り，柳泉園プラントの臭気の程度を判断す るととができよう.

ト・騒音および振動

柳泉園プラントにおける騒音および振動とも $50 \mathrm{~dB}(\mathrm{~A})$ 以下で，境界線上での規定值を満足している.

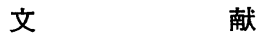

1）工場操作ンリーズ，“湿式分級について”，粉粒体の分級・ 選別, p. 12 14, 化学工業社, 昭 47.

2）日本廃棄物対策促進協会, “産業廃棄物処理工学”, p. 29, 昭49.

3) Rubber and Plastics News, "Introduces New Film Recovery System", p. 5, Aug., 1973.

4) Jensen J. W., "Recycling \& Disposal of Waste Plastics", p. 219 249, Recycling \& Disposal of Solid Wastes, ann arbor Science, Jan., 1974.

5) Warner, A. J., "Recycling of Waste Materials with Particular Emphasis on Plastics", from an address given to the Canadian Society of the Plastic Industry, Toronto, Ontario, Apr., 1971.

6）工場操作ンリーズ, “コンクリート用骨材の篩分け”，節分 編, p. 114 , 化学工業社, 昭 43 .

7) 同上, “石灰工業に扔ける穊分け”, 穊分編, p. 126, 化学 工業社, 昭43.

8）同上，“製鉄業に扔ける篩分け”，篩分編，p. 129, 化学工業社, 昭 43 .

9）同上 “BHC の分級”，粉粒体の分級・選利， p. 103 $\sim 105$, 化学工業社, 昭 47 .

10) 都市ゴミからパルプ等を回収する技術開発に必要な る調査研究専門委員会, “研究報告書”, p. $4 \sim 7$, 資源化技術協会，昭48.

11) Kohlhepp, D. H., “The Dynamics of Recycling”, Presented to the American Institute of Chemical Engineers, 78th National Meeting, Aug., 1974. 